\author{
St ud i P hilos o phic a \\ Wrat is lavi e n s i a \\ vol. XIII, fasc. 3 (2018) \\ DOI: $10.19195 / 1895-8001.13 .3 .10$
}

\author{
BARTEOMIEJ SKOWRON \\ ORCiD: 0000-0002-6544-7706 \\ Politechnika Warszawska
}

\title{
Możliwościowe ujęcie logiki praktycznej. Logika bez kantów Andrzeja Kisielewicza*
}

Andrzej Kisielewicz w książce Logika $i$ argumentacja. Praktyczny kurs krytycznego myślenia ${ }^{1}$ proponuje, abyśmy radykalnie zmienili sposób nauczania logiki praktycznej. To nie podstawy rachunku zdań oraz rachunku kwantyfikatorów (w tym tradycyjne sylogizmy) powinny być wykładane w trakcie elementarnych kursów z logiki i myślenia krytycznego. Rachunki te są ważne, ale w matematyce i naukach pokrewnych. Ich powszechne wykorzystanie w dydaktyce to wielka pomyłka i wedle Kisielewicza ślepa uliczka. Powinniśmy uczyć logiki, która jest wyczerpującą analizą rozsądnych możliwości: wniosek wynika z przesłanek, jeśli nie ma innej rozsądnej możliwości. Powinniśmy myśleć możliwościami, a nie syntaktycznymi regułami i schematami. Poniżej przedstawiam pięć komentarzy do książki Kisielewicza:

1. Przedstawiona wizja zmiany sposobu nauczania logiki praktycznej jest dobrym kierunkiem rozwoju logiki praktycznej.

2. Możliwościowe ujęcie logiki praktycznej jest de facto ontologizacją logiki.

3. Nauczanie logiki i myślenia krytycznego wymaga uzupełnienia technikami myślenia twórczego.

4. Krytyka logiki tradycyjnej i logiki formalnej przedstawiona przez Andrzeja Kisielewicza jest zbyt surowa.

5. Zdrowy rozsądek jest zwodniczy i utrwala myślowe koleiny, co nie sprzyja porządnemu myśleniu.

* Dziękuję Krzysztofowi Szlachcicowi za szczegółowe i krytyczne uwagi do pierwszej wersji tego tekstu. Uwagi te pozwoliły mi na ominięcie skrótów myślowych, nieścisłości, uproszczeń i błędów. Rzecz jasna, odpowiedzialność za wszystkie usterki, które w tekście pozostały, spoczywa na mnie.

${ }^{1}$ A. Kisielewicz, Logika i argumentacja. Praktyczny kurs krytycznego myślenia, Warszawa 2017. 
W dalszej części tekstu uzasadniam te twierdzenia, przeplatając je uwagami i komentarzami, które nasunęły mi się podczas studiowania książki. Biorę też pod uwagę komentarze i dyskusje, które miały miejsce podczas sympozjum Logika formalna $i$ zdrowy rozsacdek, wiele bowiem spraw zostało tam poruszonych i wyjaśnionych.

\section{Przedstawiona przez Kisielewicza wizja sposobu nauczania logiki praktycznej jest dobrym kierunkiem}

Komentowaną książkę dobrze się czyta, co jest niewątpliwą zaletą podręcznika, który ma trafić do szerokiego grona odbiorców i zachęcić do podnoszenia praktycznych kompetencji logicznych. Tekst przeplatany jest dowcipem, ironią, jasnymi ocenami autora, a nawet światopoglądowymi przekonaniami, choć nie zawsze jawnie wypowiedzianymi. Treść książki jest zanurzona w codzienności, podejmuje kwestie obecne w debacie publicznej, ma kontakt z materią społeczną. Myśl jest prowadzona żywo, dynamicznie, wielowątkowo, nie zawsze precyzyjnie, ale za to w sposób czytelny i zrozumiały. Książka nie jest przeładowana erudycyjnymi uwagami, setkami przypisów, bezlikiem odniesień i wpisów bibliograficznych — wszystkim tym, co, zastępując samodzielną myśl, psuje współczesną filozofię. Cytaty zamieszczone w książce są nieznanego autorstwa. Zamiast setki przypisów i erudycyjnych zestawień, pomnikowych przykładów, rozbudowanych teorii, dostajemy samodzielne, pomysłowe, skrajnie polemiczne a momentami dowcipne i — łącznie — żywe dzieło. Książka, jak przypuszczam, sprawi, że student i uczeń zainteresują się logiką, zachęci do podjęcia trudu ćwiczenia się w złożonych rozumowaniach i nieoczywistych dedukcjach, skusi też do samodzielności w praktykach myślowych.

Najbardziej popularnym_podręcznikiem logiki praktycznej w Polsce jest Logika praktyczna Zygmunta Ziembińskiego. Jest ona podstawą wielu kursów uniwersyteckich. Mam stosunkowo dobrą opinię o tej książce, czego w tym miejscu nie będę uzasadniał. Często wykorzystuję ją w swojej praktyce dydaktycznej. Niemniej nie mogę o tej książce powiedzieć tego samego, co powiedziałem wyżej o książce Kisielewicza - studenci skarżą się, że podręcznika Ziembińskiego nie da się czytać, jest bowiem niezrozumiały. Nie do końca wiem, co dokładnie sprawia trudność studentom. Być może wielu nauczycieli w tym miejscu powiedziałoby, że odpowiedzialność za to ponoszą niskie kompetencje intelektualne studentów. Z tym jednak się nie zgodzę. Prawdopodobnie właśnie winę za niezrozumienie ponosi układ treści, suchy, wyrafinowany i niedostosowany do odbiorcy język, oderwane od codzienności i nieco sztuczne przykłady, brak atrakcji dla rozproszonej, zsieciowanej i wielozadaniowej uwagi współczesnego studenta. Tego błędu w swojej książce Kisielewicz nie popełnił. Co więcej, regularnie wplatany motyw polemiczny, choć nie zawsze dobrze uzasadniony, regularne bolesne podszczypywania „logiki formalnej”, będące co najmniej działaniem zaczepnym w stosunku do środowiska logicznego, jeśli nie w ogóle wystąpieniem zbrojnym przeciwko powszechnej praktyce nauczania logi- 
ki w Polsce, to wszystko razem sprawia ${ }^{2}$, że Kisielewicz przyciąga i pobudza uwagę młodego człowieka. Uwagę, która od lat dziecięcych zanurzona jest w wirtualnych wojnach i grach komputerowych oraz jest na co dzień nasycana światami wyobrażonymi. Zwirtualizowana, odmiejscowiona i zsieciowana uwaga, występująca zawsze jako część większej pajęczyny, połączona siecią z milionami innych uwag (a w tym wielu maszyn), jest nową formą architektury poznawczej i do niej trzeba się dostosować ${ }^{3}$, jeśli chcemy być skuteczni w praktyce dydaktycznej i jeśli w ogóle tradycyjny model nauczania uniwersyteckiego ma jeszcze sens.

Kompetencje logiczne współcześnie masowo wykorzystywane są w postępującej informatyzacji świata przeżywanego, stąd należy się zgodzić z Kisielewiczem, że „,[p]rogramowanie, a szczególnie wyszukiwanie błędów, naprawianie programów, jest znakomitą lekcją praktycznego logicznego myślenia"4. Wątek ćwiczenia kompetencji logicznych poprzez naukę programowania, choć jest oczywisty dla wielu programistów i uczonych reprezentujących nauki ścisłe, nie jest, jak sądzę, dostatecznie doceniony w środowiskach logicznych związanych z naukami społecznymi i humanistycznymi. Przypomnienie tego faktu z jednej strony, a z drugiej podejmowanie również zagadnień ściśle filozoficznych (na przykład przywoływane Dialogi Lema) przez Kisielewicza w jednej książce, oceniam pozytywnie. Takie podejście łączy dwie, niestety dziś różne i utwierdzone w koniunkturalnym przekonaniu o swojej odrębności i wyjątkowości, kultury: ścisłą i techniczną oraz społeczno-humanistyczną.

Kolejnym aspektem książki, który chciałbym podnieść i pochwalić, jest to, że Logika $i$ argumentacja jest opisem doświadczenia autora. Podręczniki logiki rzadko kiedy bywają opisem doświadczeń autora, są raczej odsubiektywizowaną recytacją tych lub innych reguł wnioskowania. Dążąc do obiektywizmu, autorzy przedstawiają szereg metod i recept porządnego myślenia, najczęściej będących przepisami formalnymi, wraz z roszczeniem do ich uniwersalnej obowiązywalności - w rezultacie, tracąc kontakt z doświadczeniem, tracą kontakt z czytelnikiem. Logika praktyczna Kisielewicza to rozważanie możliwości, które zależy od wiedzy rozważającego, od jego kompetencji wyobrażeniowych, a w niektórych przypadkach i od preferencji politycznych ${ }^{5}$. Jest to logika dnia codziennego, logika myślenia na co dzień, logika oparta na doświadczeniu myślenia, prawdziwa logika praktyczna.

Józef Maria Bocheński mawiał, że logika pełni trzy zasadnicze funkcje w filozofii: paidagogos, organon i meros ${ }^{6}$. Uogólniając nieco, to znaczy rozpatrując nie samą filozofię, lecz wszelką praktykę myślenia, można powiedzieć za Bocheńskim,

\footnotetext{
${ }^{2}$ Fakt, że liczne polemiki w tekście — nawet jeśli nie zawsze w pełni uzasadnione — przyciągają uwagę odbiorcy, podniósł w trakcie sympozjum Marek Krajewski. Uświadomiłem sobie wtedy, że jest to pozytywny — nawet jeśli niezamierzony przez autora — aspekt książki.

${ }^{3} \mathrm{~W}$ rozmowach prywatnych Andrzej Kisielewicz przekazał mi, że pracuje nad ujęciem logiki praktycznej w formie tweetów, czyli bardzo krótkich twierdzeń (przypominających nieco Tractatus Wittgensteina), co uznaję za dobry kierunek, ponieważ dostosowany do obecnej architektury poznawczej.

${ }^{4}$ A. Kisielewicz, op. cit., s. 110.

${ }^{5}$ Jak twierdzi autor: „Analizowanie bieżącej politycznej debaty jest wielce ryzykowne, ponieważ trudno jest się uwolnić od dobrze uwewnętrznionych preferencji politycznych (jeśli ktoś takowe posiada)", ibidem, s. 261.

6 J.M. Bocheński, Co logika dała filozofii?, „Studia Filozoficzne” 6-7 (1988), s. 8.
} 
że logika powinna być wychowawcą, narzędziem i częścią porządnego myślenia. Wszystkie te aspekty można odnaleźć w omawianej książce. Analizuję je poniżej.

Normatywny i wychowawczy aspekt odnajduję w tym, że dla Kisielewicza

logika siłę swą ujawnia nie tylko w działaniu, w połączeniu z eksperymentami i testami, ale także we współpracy z innymi, ponieważ wspólna analiza jest w stanie znacznie skuteczniej wskazać ewentualne luki, ewentualne inne rozsądne możliwości wymagające rozważenia?

Trudno doprawdy znaleźć współczesny podręcznik logiki, w którym proponuje się grupowe przeprowadzenie rozumowań, to znaczy takie, w którym w jednym miejscu i czasie grupa osób pochyla się nad jednym problemem. W ogóle praca w grupach nie jest metodą wykorzystywaną w kursach logiki, przynajmniej w tych, z którymi się zetknąłem. W ujęciu Kisielewicza współpraca grupowa staje się integralną częścią myślenia, przynajmniej deklaratywnie, ponieważ nie widać tego w zawartych w książce ćwiczeniach, które niestety nie proponują efektywnych form pracy w grupach, poza nieokreślonymi co do formy dyskusjami. W książce pojawią się także inne wątki normatywne, autor propaguje zasadę życzliwej interpretacji ${ }^{8}$ i dialog poznawczy, ,gdzie dyskutującym przyświeca wspólny cel, tj. dojście do prawdy", a nie wygranie walki argumentacyjnej. Obraz myślenia logicznego wyłaniający się z innych podręczników do logiki, to obraz wyidealizowanego i idealnego podmiotu myślącego, przeprowadzającego rozumowania wedle uniwersalnych reguł. Jeśli tego typu podmiot podejmuje próby przekonania innego podmiotu, to ten drugi jest nie mniej wyidealizowanym dyskutantem. Tego typu podmioty niewiele mają wspólnego z podmiotowością zanurzoną w świecie wartości, serwisów społecznościowych, gier i przedmiotów wirtualnych, przedmiotów życia codziennego itd. Kisielewicz zanurza się w codzienność i odważnie burzy zachwyt nad matematyczną ścisłością i marzeniami Boole’a, aby logikę uprawiać w języku formalnym. Oczywiście idzie o logikę praktyczną, co do cenności logiki matematycznej jako takiej, nikt, kto choć odrobinę ją rozumie, nie powinien mieć wątpliwości.

Logika praktyczna odpowiada na pytanie, jak porządnie myśleć, jest etyką myśli, różnicuje rozumowania na poprawne i niepoprawne. Etyka praktyczna, podobnie, różnicuje w obrębie działań na te słuszne i niesłuszne. Obie nauki łączy roszczenie powinności: powinniśmy przecież myśleć porządnie, o ile myślimy, i powinniśmy działać słusznie, o ile podejmujemy wysiłek działania. W Logice $i$ argumentacji ukryta jest, jak sądzę, etyka bliska etyce angielskiego oświecenia moralnego ${ }^{10}$. Nie myśli dobrze ten, wedle Kisielewicza, kto opiera poprawność swoich rozumowań na wyróżnionym uprzednio schemacie formalnym — to nie forma rozumowania uprawomocnia przecież obowiązywalność rozumowania. Myśli dobrze ten, kto próbuje i analizuje, najlepiej jak potrafi, zgodnie ze swoją wiedzą i zdolnością, to znaczy z pewnym zmysłem logiczno-praktycznym. Prawo logiczne, jak interpretuję Kisielewicza, nie jest uniwersalnym prawidłem, jest tym, co jest

\footnotetext{
${ }^{7}$ A. Kisielewicz, op. cit., s. 117.

8 Ibidem, s. 51.

${ }^{9}$ Ibidem, s. 117.

${ }^{10}$ Podstawowe informacje o myśli moralnej oświecenia angielskiego czerpię z przeglądowej książki: M. Ossowska, Myśl moralna oświecenia angielskiego, Warszawa 1966.
} 
zgodne z indywidualnym zmysłem logicznym. „Podobnie jest z wzorem moralnym postulowanym przez Anthony'ego Ashley'a Coopera: jest to wirtuoz moralny, artysta życia. To jego własny smak moralny wyznacza prawo. Stąd też nie ma on możliwości, aby poobijać się o ostre kanty uniwersalności".

Usposobienie virtuoso jest zasadniczo przyjazne i skłonne do życzliwości, wyrobiony zmysł moralny pozwala na zachowanie właściwych proporcji, ogłada zaś na właściwe postępowanie. Nie potrzebuje virtuoso powinności i sankcji, tak samo, jak postulowany przez Kisielewicza podmiot myślaccy głuchy ma być na logikę formalną, w zamian zaś powinien spontanicznie słuchać swego zmysłu możliwościowego.

Jako platonik uznaję istnienie wielu aspektów uniwersalnych w logice; to, co napisałem wyżej nie oznacza, że porządne myślenie dla mnie, a o nie przecież idzie w logice, to myślenie w pełni zsubiektywizowane czy myślenie grupowe. Nie twierdzę tė̇, że nie ma obowiązujących reguł myślenia. Czym innym jest jednak filozoficzna analiza procesu myślenia i badanie poprawności reguł rozumowania, a czym innym próba przekazania tych informacji i kompetencji studentowi. Nie uczymy w Polsce dobrze logiki praktycznej, a Kisielewicz to właśnie nam chce pokazać i ma rację. Niemniej idzie dalej i stwierdza, że „[n]ie istnieją żadne ogólne prawa i zasady, którymi można by się posługiwać przy wyciąganiu logicznych wniosków"11. Z tym trudno się zgodzić. Czy potrafimy wskazać kontekst, nawet czysto praktyczny, w którym reguła odrywania nie działa? Albo prawo: jeśli $p$, to $p$ ? Wydaje mi się, że tego typu rozsądnej możliwości nie ma.

Kisielewicz proponuje również narzędzie, jak dobrze myśleć na co dzień. Jest to w miarę wyczerpujące rozważanie rozsądnych możliwości. Nie jest to narzędzie schematyczne, formalne czy uniwersalne. Niemniej jest ono ściśle związane z dziedziną, o której myślimy i w tym tkwi jego moc. Intuicja jest prosta: to, czy porządnie rozumuję, zależy od tego, o czym rozumuję i czy poprawnie to rozumowanie przeprowadzam. Poprawność rozumowania polega na odpowiedniości w stosunku do właściwości dziedziny, a nie na manipulacji logicznymi spójnikami ${ }^{12}$. Kiedy myślę o przestrzeni Hilberta lub o modelu Monstrum, kiedy myślę o przedmiotach matematycznych, to z grubsza biorąc, schematy myślenia opisane w klasycznej logice zdań obowiązują i dobrze pracują. Gdy jednak zmieniam dziedzinę przedmiotów idealnych na dziedzinę przedmiotów intencjonalnych (w rozumieniu Romana Ingardena), to nie jest prawdą, że Shrek urodził się we Wrocławiu lub się nie urodził we Wrocławiu, ponieważ nie jest w ogóle określone (przynajmniej wedle mojej wiedzy), czy się urodził — jest on przedmiotem w istocie niedookreślonym, zawiera luki w swoich określeniach. Istnieje tylko określony tak, jak określił go William Steig i jego następcy w swoich domniemaniach. Jego zawartość jest wytworem

11 A. Kisielewicz, op. cit., s. 86.

12 Szczególnie ciekawe jest zagadnienie negowania oraz pytanie, czym w ogóle jest negacja: czy jest jednoargumentowym spójnikiem zdaniowym (co zapewne krytykowałby Kisielewicz), czy funkcją zmieniającą wartość logiczną jakiegoś obiektu, czy może przeciwieństwem? A może jest odwracaniem wartości logicznej lub odwracaniem rozważanej struktury do góry nogami? Ideę negowania jako odwracania do góry nogami rozwijaliśmy w tekście B. Skowron, W. Kubiś, Negating as turning upside down, „Studies in Logic, Grammar and Rhetoric”, przyjęte do druku. 
twórczej fantazji, jego własności i określenia nie są w nim ucieleśnione. Źródłem jego istnienia jest intencjonalne sprawstwo aktów świadomości Steiga. Tożsamość Shreka jest niejako użyczona jemu przez jego twórcę. Przedmiot matematyczny w tak źródłowy sposób nie jest niedookreślony. Podstawą określeń jest on sam, a nie poznający jego własności matematyk — to samo z tożsamością przedmiotu matematycznego: nie jest ona tylko użyczonym przez matematyka momentem jego zawartości ${ }^{13}$. Przypisując przedmiotowi matematycznemu sensowną własność, tak naprawdę ją tylko uchwytujemy i opisujemy. Jeśli jest ona wyrażona w odpowiednim języku, to przedmiot ten bądź ją posiada, bądź jej nie posiada. Oczywiście może być i tak, że nie da się rozstrzygnąć, czy przedmiot ten posiada tę własność, czy nie. Niemniej przyczyną braku rozstrzygnięcia nie jest twórcza fantazja matematyka, która tego nie przewidziała, tylko rozważany przedmiot, zestaw jego wewnętrznych określeń oraz jego matematyczne osadzenie w takim, a nie innym systemie aksjomatycznym.

Różnica co do sposobu istnienia jest różnicą istotną dla sposobu myślenia o danej dziedzinie przedmiotowej. Kisielewicz tego tak nie nazywa, twierdzi raczej, że mamy niepełną wiedzę w niektórych dziedzinach, na przykład w zagadnieniach filozoficznych. Wiedza ta nie jest, jak to mówi Kisielewicz „konkretna”14. Wykłady filozoficzne, wedle autora Logiki i argumentacji, mają posmak nieścisłości i niejasności ${ }^{15}$, za którą nie przepadają studenci nauk ścisłych. Autor w tym miejscu uległ zwodniczym zabobonom ścisłości matematycznej, co wyjaśniam poniżej.

Kisielewicz niejawnie utożsamia jasność i ścisłość z jasnością i ścisłością matematyczną - to częsty i zrozumiały grzech matematyków. Co więcej:

[c]o się tyczy opracowania naszego przedmiotu, to wystarczy może, jeśli ono osiągnie ten stopień jasności, na który ów przedmiot pozwala. Nie we wszystkich bowiem wywodach należy szukać tego samego stopnia ścisłości ${ }^{16}$

— choć myśl ta znajduje się w książce Kisielewicza, nie jest jednak rozważona konsekwentnie. Jeśli poziom ścisłości zależy od przedmiotu, to znaczy, że ścisły i nieścisły w odniesieniu do rozważań matematycznych znaczy coś innego niż w odniesieniu do rozważań filozoficznych. Idąc dalej, istnieją wtedy ścisłe i nieścisłe rozważania filozoficzne, ścisłe i nieścisłe na tyle, na ile umożliwia to przedmiot namysłu filozoficznego. Dokładniej, rozważania Romana Ingardena zawarte w Sporze o istnienie świata są filozoficznie piekielnie ścisłe, myśli zaś Heraklita już takie nie są. Nie jest zatem prawdą, że każdy problem filozoficzny jest nieścisły. Zgodzę się z tym, że przedmioty matematyczne pozwalają na wyróżnienie największej ilości możliwych różnic (ilość możliwych różnic to poziom ścisłości) we własnym obrębie i to jest właśnie podstawą tego, że matematyczna ścisłość stawiana jest (słusznie)

13 Sprawa nie dotyczy przedmiotów matematycznych, niemniej w ramach uwagi wspomnę, że o tożsamości przedmiotów matematycznych może decydować niezmiennicze ich osadzenie w danej kategorii. Innymi słowy tożsamość byłaby izomorfizmem obiektów w rozważanej kategorii. Pojęcie kategorii rozumiem zgodnie z badaniami Eilenberga i Mac Lane'a.

14 A. Kisielewicz, op. cit., s. 10.

15 Ibidem, s. 11.

16 Arystoteles, Etyka Nikomachejska 1094b, tłum. D. Gromska, [w:] idem, Dzieła wszystkie, t. 5, Warszawa 2000, s. 79. 
jako wzorzec. Tyle, że niekrytyczne stawianie ścisłości matematycznej jako wzorca w swej konsekwencji doprowadziło do krytykowanego przez Kisielewicza nauczania logiki formalnej jako logiki praktycznej. Co więcej, można z sukcesem prowadzić rozważania etyczne ściśle, jak i nieściśle. To, że niektóre problemy filozoficzne nie są jasne, nie oznacza, że po ścisłej analizie nie stają się jasne. Obraz „humanistów” w wyobraźni ,ścisłowców" jest wciąż nieadekwatny i wypełniony zabobonami. O humanistycznych mitach na temat „ścisłowców” nie będę wspominał, niemniej jest oczywistością, że „humaniści” nie pozostają dłużni.

Stosunek filozofów do samej filozofii jest (co najmniej) dwojakiego rodzaju: (a) filozoficzny autoerotyzm - filozofowie ci szczycą się tym, że są filozofami, podkreślają to w każdym możliwym miejscu, napawają się filozofią i są z tego dumni - oraz (b) filozoficzne wyparcie - ci filozofowie odżegnują się od filozofii, podchodzą z dystansem, czasem unikają filozofii jak ognia, bojkotują filozofię, wciąż ją - paradoksalnie - uprawiając. Logika jest częścią filozofii i jest to widoczne w książce Logika $i$ argumentacja. Niemniej autor, w przeciwieństwie do mojej, przyjął postawę filozoficznego wyparcia. Stwierdza, na przykład: „[w] niniejszym podręczniku staram się nie wdawać w filozoficzne dyskusje i prezentować tylko to, co nie wymaga żadnych wyszukanych uzasadnień"17. Wbrew deklaracjom autora, książka ta jest na wskroś filozoficzna i niejawnie opiera się na jasnym zabiegu ontologizacji logiki, o czym później.

Ostatnią i najważniejszą racją wspierającą twierdzenie, że przedstawiona wizja zmiany sposobu nauczania logiki praktycznej jest dobrym kierunkiem stanowi fakt, że proponowane narzędzia po prostu działają. Rozważanie, w miarę wyczerpujących i rozsądnych możliwości, przypadków, kontrprzykładów, możliwych stanów rzeczy - to faktyczne sposoby myślenia. Tak na co dzień myślimy, a w logice praktycznej idzie właśnie o praktykę myślenia.

W naturalny sposób powstaje pytanie, czy omawiana książka jest podręcznikiem, czy monograficznym ujęciem logiki praktycznej? Jeśli jest podręcznikiem, to z pewnością nie jest to standardowy podręcznik, w którym dokonuje się przeglądu dotychczasowych ustaleń. W książce przedstawiona jest autorska propozycja logiki praktycznej, w której nie referuje się tego, co już zrobiono. To, co zostało zrobione, w szczególności w nauce o krytycznym myśleniu i logice formalnej, po sprytnym zabiegu upostaciowienia (logika formalna jest uosobieniem złego bohatera), służy raczej jako punkt wyjścia prezentacji własnego stanowiska.

\section{Możliwościowe ujęcie logiki praktycznej jest de facto ontologizacją logiki}

Przypomnę kilka definicyjnych stwierdzeń autora:

1. Istotą logicznego rozumowania jest w praktyce rozważanie możliwości (możliwych stanów rzeczy). Logika to analiza możliwości. Wniosek uznajemy za logiczny, jeśli nie istnieje, naszym zdaniem, możliwość alternatywna ${ }^{18}$.

\footnotetext{
17 A. Kisielewicz, op. cit., s. 86 .

18 Ibidem, s. 62.
} 
2. Natomiast warto zwrócić uwagę, że ta powszechnie stosowana w dedukcji metoda jest naturalnym elementem analizy możliwości — rozważaniem możliwości przeciwnej, a więc »czy możliwe jest, żeby było inaczej? «19.

3. Logika to analiza możliwości rozsądnych ${ }^{20}$.

4. Wniosek jest logiczny, jeśli (oczywiste jest, że) nie ma innej rozsądnej możliwości ${ }^{21}$.

5. Rozumowanie jest (logicznie) poprawne, jeśli jest zupełne ze względu na wszystkie rozsądne możliwości ${ }^{22}$.

Przywołam kilka określeń ontologii:

1. , ,...] ontologia rozważała byt w ogóle [...] od strony koniecznych i dostatecznych warunków jego możliwości $[\ldots]^{\prime \prime 23}$.

2. Christian Wolff: ontologia to nauka „o bycie w ogóle, o ile jest bytem”, przy czym Wolff twierdził: „,b]ytem nazywamy to, co istnieć może, czyli czego istnienie nie jest sprzeczne” oraz dalej: „co jest czymś możliwym [...], jest bytem"24. W ontologii Wolffa to dzięki swojej istocie byt jest i jest w ogóle możliwy, a jego poznanie jest pewnym wglądem w jego istotę, w organizującą przedmiot strukturę. Prowadzi to do uznania prymatu bytu w stosunku do poznania, prymatu istoty w stosunku do sądów logicznych (lub jeszcze inaczej: prymat prawdy transcendentalnej w stosunku do prawdy logicznej).

3. Roman Ingarden: „zagadnienia ontologiczne dotyczą czystych możliwości i koniecznych związków między czystymi jakościami idealnymi, w których owe możliwości mają swoje źródło"25.

4. Jerzy Perzanowski: „Ontologia jest teorią tego, co jest: teorią bytu. Rozważa więc całe uniwersum — ogół tego, co możliwe — opisując i klasyfikując jego obiekty oraz dociekając zasad jego budowy; zasad organizujących obiekty ontyczne (poszczególne byty) w całość - Byt"26.

Zauważmy, że określenia te są z sobą ściśle powiązane. Ontologię definiuje się współcześnie jako naukę o tym, co jest możliwe, jako analizę zawartości idei możliwości. Ontologia współczesna jest na wskroś modalna. Byt jest właśnie tym, co wyznacza swoim zakresem możliwość. Ontologia bada możliwości w pewnej ogólności, niezależnie od dziedziny, w której są one możliwościami. Kisielewicz, definiując logikę jako rozważanie możliwości (a nie badanie poprawności rozumowań albo badanie praw prawdziwości), zbliżył się zatem do rozważań czysto ontologicznych. Analizy możliwości są w istocie analizami ontologicznymi.

I nie idzie tutaj tylko o słowa, finalnie nie ma to przecież znaczenia, czy nazwiemy nasze rozważania ontologicznymi, czy logicznymi. Idzie o sposób myślenia i nastawienia do porządnego myślenia. Zasadniczo inne narzędzia praktyczne oferuje w nauczaniu ontologia, a inne logika formalna. Analiza zawartości idei - główna metoda ontologiczna — nie jest analizą formalno-logiczną, w której odnajduje się odpowiedni wzorzec rozumowania i następczo sprawdza się, czy dane rozumowanie pod ten wzorzec podpada. Badanie zawartości idei koncentruje uwagę na idei, którą się zajmujemy, bada się zawartość, mówiąc językiem Ingardena, stałych i zmiennych tych idei. Bierze się pod uwagę sposób istnienia

\footnotetext{
19 Ibidem, s. 66.

20 Ibidem, s. 80.

21 Ibidem, s. 81.

22 Ibidem.

${ }^{23}$ B. Paź, Ontologia, [hasło w:] Powszechna encyklopedia filozofii, t. 7, Lublin 2006, s. 810.

${ }^{24}$ Ibidem, s. 812. Określenie ontologii w ujęciu Wolffa podaję za hasłem Ontologia autorstwa B. Pazia w Powszechnej encyklopedii filozofii (ibidem, s. 811-812).

25 R. Ingarden, Spór o istnienie świata, t. 1, Warszawa 1960, s. 44.

${ }^{26}$ J. Perzanowski, Ontologie $i$ ontologiki, ,Studia Filozoficzne” 6-7 (1988), s. 87.
} 
przedmiotu, którego dotyczy rozumowanie - staje się twarzą w twarz z dziedziną, o której się rozumuje.

Wielu logików formalnych krytycznie odnosi się do propozycji Kisielewicza, co widać w tym tomie, właśnie dlatego, że analizy ontologiczne nie są częścią kursów logiki — są „obcym” elementem dla logiki. Ontologia i logika, wbrew swojej naturze, chodzą współcześnie własnymi ścieżkami. Organizacyjnym wyrazem tego faktu jest choćby to, że logicy na polskich uniwersytetach pracują najczęściej w Katedrach Logiki, Logiki i Metodologii Nauk, Logiki Matematycznej lub Katedrach Podstaw Matematyki. Nie znam polskich Katedr Logiki i Metafizyki, a tym bardziej Katedr Filozofii Moralnej, Logiki i Metafizyki. Nie jest jednak trudno przy pomocy Google'a odnaleźć tego typu katedry lub stanowiska na dobrych uniwersytetach. Pamiętam swoje zdziwienie, kiedy będąc studentem, dowiedziałem się, że znany filozof Timothy Williamson był profesorem logiki i metafizyki na uniwersytecie w Edynburgu. Pytałem sam siebie: co ma wspólnego jedno z drugim, oprócz tego, że metafizycy nie znają bądź z pogardą odnoszą się do logiki, a logicy podśmiechują się z metafizyków? Oczywiście to były tylko pierwsze wrażenia. Później odkryłem, że stosunkowo intensywny rozwój ontologii formalnej, również w Polsce, jest odpowiedzią na głębokie związki ontologii i logiki, a zauważana wcześniej niezgoda i krzyżowanie mieczy opierały się na zwykłej ignorancji.

Możliwościowe ujęcie logiki nie jest niefilozoficznym, takim po prostu, przemyśleniem spraw nauczania logiki. Nie jest niewinnym badaniem. Zanurzone jest w pewnej silnej tradycji ontologicznej, którą można nazwać ontologicznym esencjonalizmem. Aby badać możliwość, trzeba założyć, że można to w ogóle robić. Można tak robić tylko wtedy, gdy uprzednio założy się istnienie pewnych struktur obdarzonych istotami. W tym kontekście zapewnienia Kisielewicza: „staram się nie wdawać w filozoficzne dyskusje i prezentować tylko to, co nie wymaga żadnych wyszukanych uzasadnień"27 potwierdzają tylko przynależność do grupy filozofów wypierajacych.

Moja zasadnicza życzliwość do pomysłów zawartych w książce zbudowana jest również na tym, że w teoretycznej robocie filozoficznej odnajduję zbieżność poglądów swoich i (tych niejawnie założonych) Kisielewicza. Ontologia esencji była i jest wysoce teoretycznym konstruktem. Perzanowski twierdził nawet, że tego typu ontologia jest najogólniejszą ze wszystkich możliwych nauk. Jest abstrakcyjna i bynajmniej niełatwa w nauczaniu — stąd też nie tak popularna wśród studentów, jak inne ontologie, w szczególności te, które nie wymagają od uczącego się wielogodzinnego skupienia. Okazało się jednak, ku mojej uciesze, że być może nie jej zasadnicze treści, które nie są przystępne, lecz styl „możliwościowego myślenia” ma zastosowanie praktyczne i to $\mathrm{w}$ dodatku w logice.

Jeśli powiem, że kolejnym z silnych ontologicznych założeń propozycji Kisielewicza jest to, że przedkłada istotę ponad istnienie, to Kisielewicz prawdopodobnie odpowie, że jest to twierdzenie zbyt wyszukane i daleko poza zdrowym rozsądkiem. Niemniej tak właśnie twierdzę. Możliwościowe myślenie jako takie

${ }^{27}$ A. Kisielewicz, op. cit., s. 81. 
jest wyrazem_przekonania o prymacie istoty (wyznaczajacej to, co jest możliwe) w stosunku do istnienia. Spróbuję uzasadnić to, używając argumentacji matematyka. William Feller, niejako tłumacząc się z tego, że w swoim podręczniku do rachunku prawdopodobieństwa rozważa nieistniejące obiekty, podaje argument, że są one możliwe oraz, że mogą zaistnieć, a to już wystarcza do tego, aby je sensownie rozważać:

[...] praktyczne i użyteczne modele mogą się odnosić do światów nieistniejących. Na przykład miliardy dolarów zainwestowano w budowę automatycznych central telefonicznych. Wszystkie one są oparte na prostych rozważaniach probabilistycznych, w których porównuje się różne możliwe układy; wybiera się następnie teoretycznie najlepszy, a inne nigdy nie będą istniały ${ }^{28}$.

W tym miejscu tylko wspomnę, że w Polsce zabiegu ontologizacji logiki w ścisłym sensie dokonał Roman Ingarden. Przeprowadził to inaczej niż autor Logiki $i$ argumentacji. Zinterpretował zagadnienia logiczne $\mathrm{w}$ pieczołowicie przez siebie budowanym systemie ontologicznym, w szczególności dokonał analizy sądu warunkowego z perspektywy zależności ontologicznej. Warto dodać, że Ingarden również przeprowadził ostrą krytykę logiki formalnej ${ }^{29}$.

Na koniec wątku ontologicznego dodam na marginesie, że możliwościowe myślenie zauważono i zbadano w kontekście przeprowadzania rozumowań przez psychologów poznawczych. Jedną z koncepcji wyjaśniających przeprowadzanie rozumowań dedukcyjnych jest tak zwana teoria modeli umysłowych ${ }^{30}$. Rozumujacc, wyobrażamy sobie dziedziny, do których się odnosimy, następnie dokonujemy manipulacji na reprezentacjach tych dziedzin. Oczywiście dziedziny te mogą być przeróżne: od świata realnego, przez wirtualne procesy — słowem wszystko, o czym można myśleć. „Każdy model umysłowy reprezentuje możliwość, a jego struktura i treść ujmuje to, co jest wspólne różnym sposobom zaistnienia tej możliwości”31. Rozumowanie nie opiera się tylko na wyobrażeniach, bo one są zbyt ubogie - nie zawierają elementów abstrakcyjnych, jak na przykład negacja: jak bowiem można wyobrazić sobie treść nazwy nie-Wrocław? Teoria modeli umysłowych w swych zasadniczych twierdzeniach jest zbieżna z propozycjami Kisielewicza — co dla porządku odnotowuję.

${ }^{28}$ W. Feller, Wstęp do rachunku prawdopodobieństwa, tłum. R. Bartoszyński, B. Bielecki, Warszawa 2007 , s. 13 .

29 Ingardenowska analiza sądu znajduje się w R. Ingarden, O sądzie kategorycznym i jego roli w poznaniu, [w:] idem, Z teorii jezzyka i filozoficznych podstaw logiki, Warszawa 1972, s. 222-259 oraz w 22 rozdziale książki R. Ingarden, O dziele literackim. Badania z pogranicza ontologii, teorii języka $i$ filozofii literatury, Warszawa 1988. Analiza sądu warunkowego znajduje się w R. Ingarden, O sądzie warunkowym, [w:] idem, Z teorii języka i filozoficznych podstaw logiki, Warszawa 1972, s. 271-325. Zagadnienie ontologizacji logiki oraz fenomenologicznej krytyki logiki formalnej omawiałem w B. Skowron, Fenomenologia $i$ logika, [w:] Wprowadzenie do fenomenologii. Interpretacje, zastosowania, problemy, t. 2, W. Płotka (red.), Warszawa 2004, s. 295-341.

${ }^{30}$ P.N. Johnson-Laird, Rozumowania dedukcyjne, [w:] Psychologia poznawcza w trzech ostatnich dekadach XX wieku, Z. Chlewiński (red.), tłum. R. Balas et al., Gdańsk 2007, s. 212-238, w szczególności zob. strony 218-220.

31 Ibidem, s. 219. 


\section{Nauczanie logiki i myślenia krytycznego wymaga uzupełnienia technikami myślenia twórczego}

Etycy mają ambicje, aby ich studenci przeprowadzali poprawne rozumowania praktyczne; filozofowie społeczni chca, by ich studenci byli krytyczni i podejrzliwi; matematycy i filozofowie analityczni marzą, by przeprowadzane rozumowania były logiczne; pedagodzy i psycholodzy nawołują do myślenia twórczego. Każda grupa nauczycieli jest w jednym zgodna: występują głębokie deficyty w myśleniu odpowiednio praktycznym, krytycznym, logicznym i twórczym. Zapominamy w procesie dydaktycznym, że myślenie jest organiczną całością, w obrębie której wyróżnienie poszczególnych części, praktycznej, twórczej itd. oraz dalsze ich usamodzielnienie jest $\mathrm{w}$ istocie zubożeniem całego procesu. Podzieliliśmy między sobą kompetencje studentów podług specjalizacji Wydziałów i Instytutów i tak, narcystycznie przekonani o swojej odrębności, ich nauczamy. Szczególnie doskwierająca jest odrębność i niezależność logiki od psychologii, a w konsekwencji powszechna odrębność nauczania myślenia twórczego i myślenia logicznego. Jest nierzadkim zjawiskiem wśród psychologów i pedagogów żywienie zabobonnego przekonania, że logiczne myślenie, ścisłe formułowanie myśli jest nietwórcze ${ }^{32}$, a nawet, że twórczość poprzez schematyzm i automatyzm zostaje osłabiona. Jest zabobonem wśród logików, że kursy twórczego myślenia to koniunkturalny wymysł psychologów, a z myśleniem prawdziwym mają tyle wspólnego, co płyta wiórowa z drewnem ${ }^{33}$. Zaletą książki Andrzeja Kisielewicza jest to, że te dwa aspekty myślenia: logiczny i twórczy na powrót łączy — a łączy je dlatego, że oparł swoją książkę na doświadczeniu pracy twórczej, a nie na erudycyjnym zestawieniu osiągnięć poprzedników. Zagadka o autobusie podana przez autora ${ }^{34}$ jest znaną łamigłówką wykorzystywaną na kursach twórczego myślenia. Co więcej, autor wprost nawołuje do twórczości jako takiej. Przy zagadce o zapałkach stwierdza: ,,[z]agadka ta jest przykładem, że w rozwiązywaniu problemów trzeba próbować wyjść poza schemat"35. Wychodzenie poza schemat jest przestrukturalizowaniem wyjściowego problemu, co jest podstawową

32 Zob. prześmiewczy komentarz do roli definicji K. Szmidt, Trening kreatywności. Podręcznik dla pedagogów, psychologów i trenerów grupowych, Gliwice 2013, s. 97. Wymowna jest też dedykacja Szmidta: „Tym wszystkim aktualnym i byłym uczniom, którym — tak jak mnie — wychowawcy matematycy przez całe lata wmawiali, że »nic z nich nie będzie«. Tym wszystkim krytykom, którzy z krytyki tego, co stworzyli inni ludzie, uczynili sens swego życia i motor kariery naukowej. Krytykujcie, ale najpierw twórzcie!”. Por. E. Nęcka, Psychologia twórczości, Gdańsk 2001, s. 69-70: „Obecnie odchodzi się od poglądu, że myślenie twórcze opiera się na heurystykach, czyli ogólnych wskazówkach ukierunkowujących proces poszukiwania rozwiązania, podczas gdy myślenie nietwórcze miałoby wykorzystywać algorytmy [...]".

33 Prawdopodobnie jest to pokłosie tak zwanego antypsychologizmu w filozofii reprezentowanego przez ojców filozofii ścisłej Fregego, Husserla i Twardowskiego. Krótko mówiąc, przedmioty logiki nie są przedmiotami psychicznymi, posiadają swoje własne ufundowanie w bycie, a nie w indywidualnym podmiocie - tak twierdzą antypsychologiści, w tym wielu logików. Nie mam co do tego wątpliwości, że przedmioty logiczne takie właśnie są, niemniej czym innym jest ontologiczny spór o przedmiot logiki, a czym innym praktyczna metoda nauczania porządnego myślenia. Wydaje się, że różnice natury teoretycznej pomiędzy psychologami i logikami (z grubsza biorąc) zwyciężyły, tym samym odbiegły od siebie metody nauczania psychologii i logiki.

${ }^{34}$ A. Kisielewicz, op. cit., s. 36.

35 Ibidem, s. 28. 
techniką twórczej aktywności. Omawiając rozwiązanie zagadki o dziewięciu punktach, autor twierdzi: „w rozwiązywaniu problemów trzeba próbować przełamywać myślowe schematy"36 i wreszcie: „logiczne myślenie jest czynnością twórczą i często wymaga podejścia oryginalnego i przełamania myślowych schematów"37.

Logiczne i twórcze myślenie idą w książce w parze, choć wydaje się, że autor tej paralelności nie wykorzystał w pełni. Podręcznik byłby skuteczniejszy w ćwiczeniu się w porządnym myśleniu, gdyby autor uzupełnił zawartość o kilkanaście ćwiczeń z tak zwanego treningu kreatywności. W kolejnym wydaniu proponuję dodać ćwiczenia rozgrzewkowe ${ }^{38}$, które przygotowują umysł do wysiłku oraz dynamizują grupę uczestników. Ciekawym dla koncepcji autora byłoby ćwiczenie zawieszające prawa nauki (badanie innych możliwości): studenci otrzymuja piłeczkę od prowadzącego i w dowolny sposób po kolei przerzucają ją między sobą. Osoba posiadająca piłkę musi odpowiedzieć na pytanie typu: co by było, gdyby ludzie nie umierali? lub co by było, gdyby nie było siły ciężkości? lub co by było, gdyby istniała tylko jedna płeć? Po udzieleniu odpowiedzi na to pytanie, rzuca piłkę do następnego uczestnika itd. Bardzo dobrym przeglądem tego typu ćwiczeń jest Trening kreatywności Krzysztofa Szmidta ${ }^{39}$.

Pytanie o to, czym jest myślenie twórcze jest tak samo trudne, jak pytanie o to, czym jest myślenie logiczne. Niemniej odpowiedzi zarówno na pierwsze, jak i drugie istnieje wiele. Popularnym ujęciem twórczego myślenia jest podejście Guilforda ${ }^{40}$, który procesy twórcze nazywa procesami rozbieżnymi. W koncepcji tej wyróżnia się trzy ich własności: płynność, giętkość i oryginalność (spotykany tė̇ jest czwarty wymiar: staranność). Płynnie myśli ta osoba, która potrafi w bardzo krótkim czasie wygenerować wiele pomysłów; giętki umysł ma ten, kto potrafi w krótkim czasie wytworzyć jakościowo różne myśli, potrafi zmieniać kierunek poszukiwań; oryginalność jest zdolnością wychodzenia poza narzucające się rozwiązania, prowadzi do sensownych, choć często niekonwencjonalnych i nieoczekiwanych rezultatów. Własności te są zoperacjonalizowane, na przykład ilością podanych pomysłów w ściśle określonym czasie. Brakuje w Logice i argumentacji odniesień choćby do tego popularnego ujęcia twórczości. Nie z powodu akademickiego pominięcia (wiadomo: „wszystko już było”, lecz dlatego, że samoświadomość przeprowadzanych rozumowań ma wpływ na ich jakość. Gdyby student wiedział, że „przełamywanie schematów” można ująć ściśle i konkretnie, używając słów autora, jako poszukiwanie wielu różnorodnych i niepowtarzalnych pomysłów wedle recepty Guilforda, to później w praktycznych sytuacjach rozwiązywania problemów, mógłby z nich skorzystać, wiedząc uprzednio, że mogą być pomocne, będąc jednocześnie łatwymi w zastosowaniu i zapamiętaniu.

W przywoływanym już podręczniku Trening kreatywności Szmidt wyróżnia trzy formy twórczego myślenia: pytajne, kombinacyjne i transformacyjne. Myślenie kombinacyjne jest myśleniem łączącym części w całość, jest syntetyzowaniem

\footnotetext{
${ }^{36}$ Ibidem, s. 34.

${ }^{37}$ Ibidem, s. 85.

${ }^{38}$ Zob. rozdział 3 Rozgrzewka twórcza, [w:] K. Szmidt, op. cit., s. 39-61.

${ }^{39}$ Ibidem.

${ }^{40}$ Zob. E. Nęcka, op. cit., s. 26-29.
} 
i zespalaniem elementów. Przykładem zastosowania niech będzie przygotowanie sałatki owocowej lub połaczenie usług skrzynki odbiorczej, interaktywnej mapy, telefonu, kalkulatora, karty płatniczej i innych funkcji w smartfonach. Myślenie pytajne zasadza się na gotowości do zdziwienia, dostrzegania problemów, przeprowadzania problematyzacji, eksploracji nowych przestrzeni oraz formułowania i przeformułowania pytań. Myślenie transformacyjne to myślenie przekształcania tego, co zastane w coś innego, na przykład zmienianie własności przedmiotu, procesu lub stanu rzeczy, modyfikowanie, redefiniowanie i temu podobne. Przykładem przekształcenia może być wariacja muzyczna lub ułożenie tematycznej postaci z klocków Lego. W matematyce ten typ myślenia jest widoczny w teorii kategorii zapoczątkowanej przez Eilenberga i Mac Lane'a, w której morfizm (inaczej nazywany strzałką) odpowiada za proces przekształcania, również w przypadkach abstrakcyjnych struktur. Wszystkie te typy myślenia — zarówno problematyzowanie, łączenie, jak i przekształcanie — są potrzebne w możliwie wyczerpującej analizie możliwości proponowanej przez Kisielewicza. Stąd proponowałbym, aby w przyszłości uzupełnić Logikę $i$ argumentację ćwiczeniami zaproponowanymi przez Szmidta lub Nęckę ${ }^{41}$.

Autor wielokrotnie ${ }^{42}$ podkreśla rolę wyobraźni w rozważaniu możliwości, w szczególności w twórczym uprawianiu matematyki. Wyobraźnia jest chyba zdolnością umysłu najczęściej przywoływaną przez uczonych, którzy twórczo zajmują się nauką. Wypowiedzi Einsteina o tym, że myślał, posługując się żywymi wyobrażeniami wzrokowymi, należą już do popkultury naukowej ${ }^{43}$. Niemniej proces twórczy jest o wiele bardziej złożony i o wiele więcej o nim wiemy, niż można by na podstawie lektury Logiki i argumentacji mniemać. Biorą w nim udział różne zdolności umysłu ${ }^{44}$ : uwaga (skupienie i skierowanie lub roztargnienie i rozproszenie, mechanizm wykorzystania przypadkowych wskazówek, rozszerzanie pola, wglądy, filtry uwagi, zasoby uwagi, procesy przeduwagowe), percepcja (znaczenia ukryte we wrażeniach wzrokowych, wybiorczość, projekcje własnych stanów psychicznych na spostrzegany obiekt, prawa postaci, organizacja percepcji, interpretacje percepcji, preferencje percepcji, unikanie porządku narzucającego się), kategoryzowanie i wiedza pojęciowa (otwarcie granic kategorii, poszerzanie pola semantycznego, redefinicje obiektów, syntezy pojęciowe, zmiany kontekstu, rewolucje pojęciowe, uplastycznienie rdzeni pojęciowych) oraz pamięć (wybiórcze i alternatywne kodowanie, skuteczność przywoływania pamięciowego, utrata informacji i wybiórcze zapominanie, olśnienie, globalne przeszukiwania, struktury pamięci) oraz samo myślenie (heurystyki, rozbieżność i zbieżność, aktywność, upraszczanie, redefiniowanie, zastępowanie, analogie, metafory, sztywność, giętkość, płynność, oryginalność) oraz poznanie własnych procesów poznawczych (planowanie i nadzór czynności poznawczych, analiza informacji zwrotnych). Dodatkowo procesy twórcze zanurzone są w pewnej kulturze społecznej, procesach emocjonalnych i motywa-

\footnotetext{
${ }^{41}$ Innym popularnym zestawem ćwiczeń z zakresu treningu twórczości jest książka E. Nęcka, Trening twórczości. Podręcznik metodyczny, Kraków 1989.

42 A. Kisielewicz, op. cit., s. 12, 63, 73, 77, 80 itd.

43 E. Nęcka, Psychologia twórczości, s. 62.

${ }^{4}$ Podane zdolności umysłowe wymieniam za: ibidem, s. 53-75.
} 
cyjnych, indywidualnych stylach poznawczych ${ }^{45}$. Idąc dalej, już te wymienione hasłowo przedmioty intensywnych badań współczesnych nauk społecznych i humanistycznych wskazują, że spenetrowaliśmy procesy świadome i świadomość jako taką dogłębnie. Wiemy wiele i niejednokrotnie mamy bardzo szczegółowo opisane dane - oczywiście na tyle szczegółowo, na ile pozwala dziedzina. Ani autor, ani przywoływany przez niego filozoficzny autorytet nie mają więc racji, twierdząc, że „tym, co to jest świadomość i jak powstaje, nie wiemy na razie praktycznie nic (co potwierdza sam Searle)"46.

Krytyczny czytelnik mógłby w tym miejscu powiedzieć, że czy innym jest istota świadomości i pytanie o jej źródła i sposób powstania, a czym innym momenty świadomości typu uwaga, pamięć itd., które wymieniłem powyżej. Pytanie o to, czym jest świadomość, w szczególności czysta świadomość, było pytaniem wielokrotnie stawianym i rozważanym. Niech ilustracją będą analizy czystej świadomości Romana Ingardena oraz ich rezultat, to znaczy 15 twierdzeń dotyczących czystej świadomości. Ingarden podaje je w drugim tomie Sporu o istnienie świata ${ }^{47}$. Czytelnik negatywnie nastawiony do metafizyki i analiz ontologicznych mógłby powiedzieć, że to wciąż nie jest adekwatna odpowiedź na pytanie o świadomość i jej źródła, ponieważ adekwatne odpowiedzi powinny być odpowiedziami naukowymi, a nie metafizycznym. Niemniej stawiając czysto metafizyczne pytanie, należy się spodziewać przede wszystkim metafizycznej odpowiedzi. Filozofowie, co najmniej od czasów Platona i Arystotelesa, odpowiadali na pytanie o świadomość i jej źródła — najczęściej proponując wyjaśnienia tego, czym jest i skąd pochodzi dusza. Chyba w każdym wielkim systemie metafizycznym można znaleźć takie lub inne określenie duszy i zjawisk świadomych. Nie jest prawdą, że nic nie wiemy o świadomości i jej powstaniu. Przeciwnie, spektrum gotowych odpowiedzi w tej sprawie jest zdumiewająco szerokie.

Od dziesięciu lat prowadzę kursy z myślenia krytycznego. To nie dużo, niemniej moje doświadczenie jest różnorodne. Prowadziłem zajęcia zarówno dla uczniów z wrocławskich szkół średnich ${ }^{48}$, jak i studentów kierunków humanistycznych (w szczególności filozofii) na Uniwersytecie Wrocławskim. Uczyłem także doktorantów Akademii Sztuk Pięknych im. Eugeniusza Gepperta we Wrocławiu. W ostatnich latach prowadzę przede wszystkim zajęcia ze studentami nauk ścisłych i technicznych z Politechniki Warszawskiej. Moje doświadczenia wskazują, że łączenie technik logiki praktycznej (w tym też fragmentów logiki formalnej i teorii argumentacji) z treningiem kreatywności (i autentycznie grupowymi sposobami rozwiązywania problemów) są dobrze przyjmowane i oceniane przez studentów ${ }^{49}$.

45 Przegląd tych zagadnień przedstawia książka E. Nęcka, ibidem.

46 A. Kisielewicz, op. cit., s. 253.

${ }^{47}$ R. Ingarden, Spór o istnienie świata, t. 2, Ontologia formalna. Część 2: Świat i świadomość, Warszawa 1987, s. 243-244.

${ }^{48}$ Zob. B. Skowron, Komunikat o warsztatach logiczno-krytycznych we wroctawskich liceach, ,Edukacja filozoficzna" 55 (2013), s. 95-100.

${ }^{49}$ Ciekawym i praktycznym zestawieniem metod matematycznych z metodami twórczego myślenia jest książka A. Kaufmann, M. Fustier, A. Drevet, Inwentyka. Metody poszukiwania twórczych rozwiazań, Warszawa 1975. 
Co więcej, doświadczenie z przeprowadzonych warsztatów z krytycznego myślenia we wrocławskich liceach wskazuje na to, że młodzież jest krytyczna, podejrzliwa, nienaiwna, ale... aż nadto! Sceptycyzm i zdrowa podejrzliwość doprowadzone do skrajności krępują umysł, tępią odważną myśl, ograniczają samodzielność myślową, kwaszą charakter i obniżają dynamikę podejmowanych działań. Myślenie krytyczne musi zostać wypełnione myśleniem niebanalnym, nienaiwnym, odważnym - myśleniem twórczym. Tym bardziej się cieszę, że autor bazując na doświadczeniu matematycznym, doszedł do wprowadzenia elementów treningu twórczości do logiki praktycznej.

\section{Krytyka logiki tradycyjnej i logiki formalnej Andrzeja Kisielewicza jest zbyt surowa}

Przypomnę kilka wypowiedzi Kisielewicza o logice formalnej:

1. Stoję na stanowisku, że dziedzina logiki stanowi znakomity przykład tego, że rozwój nauki ma swoje ślepe uliczki ${ }^{50}$.

2. Moim zdaniem, jeśli chodzi o zrozumienie mechanizmów praktycznego logicznego myślenia, mamy do czynienia z wielką poznawczą porażką. Bardzo mocnym argumentem na rzecz tej tezy jest porażka tzw. logicznego podejścia w dziedzinie sztucznej inteligencji, która sama w sobie jest ważnym i pouczającym przykładem na to, jak bardzo nauka może się mylićs1.

3. Najbardziej szkodliwa jest płynąca z nich sugestia, że poprawne i skuteczne myślenie zależy od form zdań używanych we wnioskowaniu ${ }^{52}$.

4. Osiągnięcia logiki formalnej w tym zakresie można streścić w postulacie naprawy języka naturalnego przez wyrugowanie terminów nieostrych, wieloznacznych, staranne definiowanie pozostałych i ujednoznacznienie gramatyki. Język naturalny — zdaniem logików formalnych - ma różne wady, takie jak wieloznaczność i nieostrość, nie do końca sprecyzowane zasady gramatyki, zależność znaczeń od kontekstu itp. Języki formalne konstruowane przez logików, czy to na potrzeby matematyki, czy informatyki, nie mają tych wad. Można powiedzieć, że udało się całkowicie naprawić język matematyki i dzięki temu usunąć z tej dziedziny wszelkie niejasności ${ }^{53}$.

I wreszcie:

5. Gdy logik formalny złamie nogę i prosi mnie, abym natychmiast wezwał pogotowie, wówczas mojego zastrzeżenia, że nie jest to zbyt precyzyjne określenie, z pewnością nie przyjmie z pedagogiczną aprobatą. Oczekuje ode mnie »chwycenia w pół słowa« tego, o co mu chodzi, i podjęcia stosownego działania $^{54}$.

Krytyka logiki formalnej jest szczególnie dotkliwa. Poprowadzona jest bowiem z pozycji wewnętrznej dla logiki — autor Logiki i argumentacji jest wszak znanym

\footnotetext{
${ }^{50}$ A. Kisielewicz, op. cit., s. 86.

51 Ibidem, s. 87.

${ }^{52}$ Ibidem.

53 Ibidem, s. 121.

${ }^{54}$ Ibidem, s. 126.
} 
logikiem ${ }^{55}$. Logika formalna była wielokrotnie krytykowana ${ }^{56}$ z różnych pozycji filozoficznych, często bez żadnych podstaw — na przykład słyszalne są głosy filozofów stroniących od logiki, że logika od czasów Arystotelesa nie poczyniła żadnych postępów. Niemniej tak odważna krytyka pochodząca ze środowiska matematyczno-logicznego uderza z podwojoną siłą.

Głównym argumentem ${ }^{57}$ przeciwko zbyt surowemu potraktowaniu logiki jest, że krytyka ta de facto nie jest skierowana w logikę formalną, tylko w sposób jej nauczania. Życzliwie interpretując słowa autora, rozumiem, że główne ostrze krytyki skierowane jest w nauczanie logiki, w którym wykorzystuje się wyłącznie logikę formalną (klasyczny rachunek zdań plus klasyczny rachunek predykatów). I tutaj zgoda. Nauczanie logiki formalnej powinno być uzupełnione elementami logiki tradycyjnej, logiki nazw, logiki definicji, logiki argumentacji, elementami treningu twórczości zestaw powinien być dobrany odpowiednio do kierunku studiów. Niemniej, wbrew Kisielewiczowi należy jasno powiedzieć, że logika formalna będąc wynikiem wielkiego wysiłku logików od czasów Arystotelesa, nie jest ślepą uliczką.. Poszukiwanie uniwersalnych form poprawności logicznej jest nie tylko ważne ze względu na bujny rozwój logiki matematycznej w XX wieku. Uniwersalność praw logicznych ma swoje uzasadnienie w uprzednio zastanych, a nie wytworzonych, relacjach pomiędzy treściami logicznymi. Związki te zachodzą pomiędzy przedmiotami, jak sądzę, idealnymi. Treści i formy logiczne są dane w źródłowej intuicji logicznej przed jakąkolwiek nauką logiki, mają same w sobie swój fundament bytowy, same noszą w sobie swoje określenia, nie powstały i nie zginą. Owszem, realizacja form logicznych w codziennych rozumowaniach nie jest zadaniem łatwym i oczywistym. W szczególności dopasowywanie nietrafionych schematów formalnych do realnych rozumowań, tak częste przewinienie wykładowców logiki, jest równie chybione, jak chybiony jest dobrany schemat. Niemniej nie każde tego typu dopasowanie jest nietrafione.

Weźmy ludowe rozumowanie: Biednemu zawsze wiatr wieje w oczy. Ci, którym wiatr w oczy wieje, są zahartowani. Stąd biedni są zahartowani. Nie jest to wydumany przykład, można się z takim rozumowaniem spotkać na co dzień - nie wymyślili tego logicy na użytek własnej nauki. Spytajmy teraz: czy ono jest poprawne logicznie? Standardowa półformalna metoda polega na narysowaniu trzech przecinających się kół, oznaczających zakresy nazw oraz odpowiednim oznaczeniu prawdziwości przesłanek, a następnie na odczytaniu prawdziwości wniosku (metoda ta opisana jest w wielu podręcznikach, przykładowo w podręczniku Logika praktyczna Zygmunta Ziembińskiego, w rozdziale Wnioskowanie dedukcyjne $i$ jego podstawy logiczne). Jeśli jest z konieczności tak, że przy

55 Propozycja teorii mnogości Kisielewicza z dwoma operatorami należenia została omówiona w Standfordzkiej Encyklopedii Filozofii. Zob. M.R. Holmes, Alternative Axiomatic Set Theories, The Stanford Encyclopedia of Philosophy (Winter 2017 Edition), red. E.N. Zalta, https://plato.stanford. edu/archives/win2017/entries/settheory-alternative/ (dostęp: 15.01.2018).

56 Jako przykład niech posłuży głos polemiczny Jana Woleńskiego: J. Woleński, Lech Witkowski jako rzecznik interesu publicznego filozofii polskiej ( $i$ w innych rolach też), „Filozofia Nauki” 10/2, (2002), s. 101-124. Zob. także B. Skowron, Fenomenologia i logika.

57 Obok argumentów wysuniętych przez L. Newelskiego i A. Biłata, z którymi się zgadzam i których tutaj nie powtarzam. 
prawdziwości przesłanek, prawdziwy jest też wniosek, to tryb sylogistyczny jest poprawny, a zatem i rozumowanie mające tę formę logiczną jest poprawne. Mówiąc językiem Kisielewicza, jeśli jest tak, że nie ma alternatywnej możliwości, aby przy prawdziwości przesłanek, wniosek był fałszywy, to rozumowanie jest logicznie poprawne. Innymi słowy, metoda autora uzasadnia, krytykowane przez autora schematy logiczne. Wniosek Ludomira Newelskiego ${ }^{58}$, że logika formalna i logika praktyczna się uzupełniają, a nie przeciwstawiają, uznaję za słuszny. Nie każde sformalizowanie i uschematyzowanie rozumowania jest jego zniekształceniem. Narzędzia formalne i półformalne niekiedy mają skuteczne zastosowanie w dziedzinie praktycznej. Tradycyjne metody w nauczaniu logiki mają więc praktyczną doniosłość, choć - co prawda - mają ograniczony zakres stosowania.

Czy faktycznie jest tak, jak autor twierdzi, że

[...] prawdziwa dedukcja (rozumowania prowadzące do wniosków koniecznych) możliwa jest wyłącznie w matematyce (w częściach rozumowań, które mają charakter matematyczny, związany ze ścisłym językiem i ścisłymi definicjami) $[\ldots]^{59}$ ?

Czy nie jest tak, że każda osoba zakładająca, że biednemu zawsze wiatr wieje w oczy oraz, że ci, którym wiatr w oczy wieje, są zahartowani nie ma innej możliwości, aby przyjąć, że biedni są zahartowani? Nie jest to rodzaj dedukcyjnego, niematematycznego i praktycznego rozumowania?

Krytykowana logika formalna, jak możemy przypuszczać z Dodatku dołączonego do książki, składa się między innymi z rachunku zdań. W rachunku zdań zachodzi zasada atomizmu logicznego, to znaczy wartość logiczna zdań złożonych zależy od wartości logicznej zdań prostych, na przykład wartość logiczna zdania nieprawda, że $p$, zależy od wartości logicznej zdania $p$. W szczególności, jeśli zdanie $p$ jest prawdą, to zdanie nieprawda, że $p$ jest fałszem i vice versa. Stąd można wyprowadzić wniosek, jak zrobił to Frege, że logika jest nauką o prawach prawdziwości. Powstaje jednak kłopot, z którym muszą sobie radzić wykładowcy logiki: a co się stanie, jeśli zdanie $p$ ma taką treść: to zdanie ma pięć słów. Zdanie $p$ jest prawdziwe, ale jego negacja nieprawda, że to zdanie ma pięć słów, jest też prawdziwe, wbrew wcześniejszemu prawu. Jeszcze większe trudności napotykamy, gdy rozważamy implikację w rachunku zdań. Prawdziwość zdania o formie implikacji zależy od prawdziwości zdań składowych, w szczególności implikacja o poprzedniku fałszywym jest zawsze prawdziwa, stąd zdanie: jeśli jestem Sokratesem, to Polska nie jest członkiem Unii Europejskiej w roku 2018 jest prawdziwe - nie jestem Sokratesem, niestety, i, na szczęście, Polska jest członkiem Unii Europejskiej w 2018 roku. Paradoksy tego typu powstają, ponieważ rozważanie tylko prawdziwości zdań (bez treści) gubi część związków bytowych.

Niemniej pomimo tych paradoksów i ku zaskoczeniu krytyków, spójniki klasycznego rachunku zdań (oraz ich modyfikacje) przez to, że są podstawą technologii

${ }^{58}$ Zob. tekst Ludomira Newelskiego zamieszczony w tym tomie Czy logika formalna ma sens? Podobne stanowisko zajął Andrzej Biłat w krytycznym artykule, również zamieszczonym w tym tomie, pod tytułem Uwagi o podręczniku „Logika i argumentacja” Andrzeja Kisielewicza.

${ }^{59}$ A. Kisielewicz, op. cit., s. 68. 
informacyjnych, wróciły do praktyki codzienności. Codzienną praktyką wirtualnych i zanurzonych podmiotów ludzkich, w tym chyba wszystkich studentów logiki, jest poszukiwanie informacji w Internecie. Bardzo popularna jest wyszukiwarka Google, w której wykorzystywane są operatory przeszukiwania przypominające spójniki logiczne. Przykładowo, jeśli użytkownik chce wyszukać informacje o tym, jak szybko jest w stanie pobiec jaguar, to zapyta jaguar szybkość. Niemniej takie zapytanie sprawi, że jako pierwsze pojawią się strony z informacją o szybkości samochodów marki Jaguar. Aby wykluczyć motoryzacyjne strony internetowe użytkownik pyta: jaguar szybkość - samochód. Operator „," działa jak negacja, to znaczy pojawiają się strony, na których występują słowa jaguar oraz szybkość, ale wykluczone są strony, na których pojawia się słowo samochód. Zastosowanie w przeszukiwaniu dużych baz danych mają również operatory OR oraz AND. Są to praktyczne operatory używane na co dzień. Można powiedzieć, że poprzez rozwój technologii informacyjnych te kompetencje, które były wyuczonymi teoretycznymi schematami, stały się pożytecznymi praktycznymi umiejętnościami ${ }^{60}$.

Współcześnie logika formalna lub logika symboliczna to w istocie logika matematyczna. Sformalizowanie badań logicznych polegało na ich matematyzacji, w szczególności na nadaniu logice formy aksjomatycznej. Aksjomatyzacja, choć to potężne narzędzie, ogranicza pole widzenia — zbyt silnie przygważdża dziedzinę do sztywnej dedukcyjnej ściany i w istocie rozdrabnia matematykę tak silnie, że po matematyce pozostaje tylko matematyczny pył ${ }^{61}$. Niemniej trudno wyobrazić sobie współcześnie alternatywne sposoby formalizacji — matematyzacja odważnie wypełniła cała przestrzeń. Czym jest jednak forma? To nie jest oczywiste pytanie. Przykładowo metafizykę formy matematycznej uprawiał Saunders Mac Lane ${ }^{62}$, który przypisywał aksjomatyzacji pewną wagę, ale nie zapominał, mając na uwadze rozwój matematyki, o rozwoju pojęciowym matematyki. Powstanie i rozwój pojęć matematycznych ma wiele składników poza aksjomatycznych, choćby sama forma matematyczna jest tym, co nie daje się ująć w karby jednej aksjomatyki. Forma matematyczna Mac Lane'a nie jest jednak najlepszym przykładem, choć ma tę zaletę w tej dyskusji, że jest bliska matematykom. O formie można myśleć ogólniej, niezależnie od matematyki — tak, jak zrobił to Roman Ingarden. Forma jest tym, co jest radykalnie niejakościowe w rozważanym obiekcie. Formą maratonu jest to, że się odbywa, że następują po sobie kolejne jego fazy, że ma początek i upragniony koniec. Inną formę ma przedmiot: jest podmiotem własności. Książka, jako przedmiot realny, nie rozgrywa się, nie ma faz we właściwym sensie tych słów. Ma swoje składniki i własności, które mogą się zmienić, kartki mogą zżółknieć, a obwoluta może się wytrzeć. Być może zatem formalizacja danej dziedziny

${ }^{60}$ Inny przykład tego typu praktycznych i powszechnych umiejętności rozważa Mateusz Kotowski w Argumenty z autorytetu a krytyczne myślenie. Uwagi na marginesie „Logiki i argumentacji” Andrzeja Kisielewicza zamieszczonym w tym numerze.

${ }^{61} \mathrm{O}$ tendencjach odwrotnych, to znaczy jednoczących matematykę, pisałem w pracy B. Skowron, Gestalty w matematyce. O unifikujacej sile sprzężé funktorowych, [w:] Problemy filozofii matematyki i informatyki, R. Murawski, J. Woleński (red.), Poznań 2018, s. 165-175.

62 S. MacLane, Mathematics. Form and Function, New York 1986, w szczególności rozdział XII The Mathematical Network, s. 409-456. 
mogłaby polegać na nadaniu radykalnego niejakościowego momentu? Rozważanie możliwości zaproponowane w Logice $i$ argumentacji jest nową propozycją formalizacji logiki praktycznej. Możliwość wprawdzie nie jest w ścisłym sensie formą przedmiotu — jest sposobem jego istnienia (obok aktualności i konieczności) — niemniej zależy zarówno od formy, jak i uposażenia jakościowego. Rozumowanie zależy od dziedziny, o której traktujemy — to Kisielewicz wielokrotnie podkreśla. Jednak czym jest ta zależność? Ona jest związana ze strukturą ontologiczną zarówno sądu, który wydajemy i za pomocą którego wnioskujemy, jak i rzeczywistości domniemanej w tym sądzie - przykładowo, forma sądu twierdzącego jest związana ze stanem rzeczy (stan rzeczy jest specyficzną formą). Nie proponuję w tym miejscu nowej formalizacji, niemniej dokonuję problematyzacji zagadnienia formy, po to, by pokazać, że zawężanie uwagi tylko do form matematycznych i matematyzacji może przesłonić przestrzeń formalizowania jako takiego. Autor Logiki $i$ argumentacji, choć nie zajmuje się deklaratywnie wyszukanymi uzasadnieniami, otworzył sposobność, aby wyszukanych ujęć form poszukiwać. I dobrze, ponieważ — jak sądzę — pozwoliło to na właściwe ukazanie roli ontologii w rozwoju logiki.

\section{Zdrowy rozsądek jest zwodniczy i utrwala myślowe koleiny, co nie sprzyja porządnemu myśleniu}

$\mathrm{Na}$ koniec rozważę sprawę zdrowego rozsądku. Logiczne myślenie to wedle autora myślenie rozważające możliwości. Niemniej rozważanie możliwości może być dowolnie głębokie i szerokie. Fantazja nie ma granic, stąd łatwo można się utopić w tym możliwościowym oceanie. Autor Logiki i argumentacji, wziąwszy tę głębię i ryzyko z nią związane pod uwagę, zaproponował jej ograniczenie do możliwości rozsądnych. Nie rozważajmy wszystkich możliwości — radzi — bierzmy tylko w miarę wyczerpujacy zestaw możliwości rozsądnych i to powinno wystarczyć — jak konkluduje — aby porządnie myśleć. Wybór rozsądnych możliwości, choć jest jak najbardziej rozsądny, budzi jednak pewne wątpliwości. Myślenie naukowe stanowi przykład porządnego myślenia, a czasem stanowi nawet wzorcową jego postać, jednak ze zdrowym rozsądkiem ma niewiele wspólnego. Który zdrowy rozsądek pomyślałby, że do opisania stanów kwantowych nadają się wektory w jakiejś abstrakcyjnej i w dodatku o nieskończenie wielu wymiarach przestrzeni Hilberta? Zdrowy rozsądek nakazuje, aby skończyć rozważanie na trzecim wymiarze przestrzeni, więcej wymiarów raczej nie przewiduje.

To, że rozsądek jest zdrowy, pociąga za sobą, że jest wspólny, przedkrytyczny, podzielany przez ogół, a tym samym staje się zależny od nastroju ogółu. Zdrowym też się jest na jeden sposób, na wiele sposobów można tylko chorować, stąd zdrowy rozsądek wymusza jedyność — nie ma przecież dwóch różnych zdrowych rozsądków. Zdrowy rozsądek jest zespołem schematów poznawczych i powiązanych z nimi reguł działania, on utwierdza nas w złudnych przekonaniach. Autor Logiki i argumentacji, choć wydostał się z kolein myślenia formalnego i kanciastego, może popaść w koleiny myślenia „zdrowego” lub „wspólnego”.

Rozważanie nieistniejących przedmiotów, a do tego prowadzi myślenie możliwościami, wydaje się niezgodne ze zdrowym rozsądkiem, który z natury nastawiony 
jest na to, co jest prawda, a w praktyce na to, co istnieje realnie. W przywoływanych badaniach psychologicznych nad modelami umysłowymi ${ }^{63}$ zakłada się tak zwaną zasadę prawdy, to znaczy ,[j]ednostki minimalizują obciążenie pamięci operacyjnej przez konstruowanie modeli umysłowych, które jawnie reprezentują tylko to, co jest prawdą, a nie to, co jest fałszem"64. Zasada ta prowadzi w praktyce rozumowania do tego, że reprezentujemy tylko te przypadki, które zachodzą (mówiąc potocznie: są prawdziwe), w szczególności: w przypadku rozumowania złożonego z przesłanek i konkluzji reprezentujemy te przesłanki, które są prawdziwe. Zdrowy rozsądek jest zatem leniwy. Z jednej strony prowadzi to do pożądanej zasady ekonomii myślenia (niektóre teorie psychologiczne rozumowań postulują, że rozumowanie jest oparte na pamiętaniu wcześniejszych wnioskowań ${ }^{65}$ ), z drugiej zaś, do zubożenia rozważanej treści, skoro zdrowy rozsądek jest nastawiony na to tylko, co jest, co istnieje realnie, a nie na to, co jest możliwe.

Jak jednak ograniczyć nieskończoną ilość przypadków i możliwości w potocznych rozumowaniach, jeśli nie poprzez rozważanie rozsądnych i w miarę wyczerpujących możliwości? Tutaj przychodzi z pomocą ontologia: rozważajmy możliwości zgodnie z ich „uposażeniami”, zgodnie z tym, co same niosą w swoich dziedzinach bytowych. Gdy rozumujemy o słusznym działaniu, bierzmy pod uwagę możliwości moralne, gdy o świecie realnym - możliwości empiryczne, gdy o przedmiotach matematycznych — czyste możliwości idealne itd. Niech rozważane możliwości będą odzwierciedleniem zastanych sytuacji, odpowiednio do ich sposobów istnienia — niech zatem ogranicza je sama ich zawartość, a nie zdrowy i zgubny rozsądek.

\section{A possibilities-based account of practical logic. Andrzej Kisielewicz's logic without edges}

\section{Summary}

In this paper I comment on the theses presented in Andrzej Kisielewicz's book entitled Logic and Argumentation. A Practical Course in Critical Thinking. The author argues that the current way of teaching practical logic is not good, because it is too much based on formal logic. It should be replaced by a comprehensive analysis of reasonable possibilities. I demonstrate that Kisielewicz's vision of changing the way in which practical logic is taught is a good one. I claim that Kisielewicz proposed a kind of ontologization of logic. I argue that teaching logic and critical thinking need to be complemented by creative thinking techniques. I do not agree with the criticism of traditional logic and formal logic made by Kisielewicz and point out that common sense - so highly valued by Kisielewicz - is deceptive and does not encourage critical thinking.

63 Zdrowy rozsądek można też rozumieć jako zmysł prawdy — niemniej gdy tak go rozumiemy, odbiegamy już od potocznego użycia słów ,zdrowy rozsądek".

${ }^{64}$ P.N. Johnson-Laird, op. cit., s. 219.

65 Zob. ibidem, s. 216. 